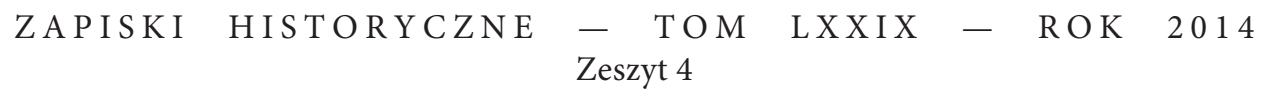

http://dx.doi.org/10.15762/ZH.2014.22

\title{
SPRAWOZDANIE \\ ZE ZJAZDU MIĘDZYNARODOWEJ KOMISJI HISTORYCZNEJ DO BADAŃ NAD ZAKONEM NIEMIECKIM W TALLINNIE
}

W dniach 26-28 IX 2014 r. w Tallinnie odbył się kolejny zjazd członków Międzynarodowej Komisji Historycznej do Badań nad Zakonem Niemieckim (Internationale Historische Kommission zur Erforschung des Deutschen Ordens) oraz zaproszonych na konferencję gości. Organizatorem zjazdu, obok Komisji, był Instytut Historii Uniwersytetu Tallińskiego (Tallinna Ülikooli Ajaloo Instituut) z Archiwum Miejskim w Tallinnie (Tallinna Linnaarhiiv). Właśnie w siedzibie archiwum znajdującej się w obrębie średniowiecznego miasta Rewla odbywały się dwudniowe obrady. Tematem przewodnim konferencji były zagadnienia życia codziennego w domach zakonu niemieckiego (Das Leben im Ordenshaus), jednak punkt ciężkości został położony na późne średniowiecze, a w znacznie mniejszym stopniu uwzględniono epokę wczesnonowożytną. Łącznie zostało zaprezentowanych 11 referatów. Spośród nich sześć dotyczyło domów zakonnych w strefie bałtyckiej - położonych w Prusach bądź w Inflantach.

W sesji przedpołudniowej pierwszego dnia obrad po otwarciu konferencji przez Udo Arnolda, przewodniczącego Międzynarodowej Komisji Historycznej, Erkiego Russowa, dyrektora Instytutu Historii, oraz Leę Kõiv, dyrektora Archiwum Miejskiego, jako pierwsza referat zaprezentowała Anette Löffler (Frankfurt a.Main), przedstawiając problematykę liturgii w zakonie niemieckim (Die Rolle der Liturgie im Leben der Ordensbrüder: Norm und Realität). Spośród trzech wyodrębnionych kręgów funkcjonowania liturgii zakonnej - kapituł katedralnych, kościołów parafialnych i domów (konwentów) zakonnych - skoncentrowała się na tych ostatnich. Dokonała systematyki źródeł, zarówno normatywnych, jak i tych pozwalających na analizę faktycznego stanu życia liturgicznego w konwentach. Zaprezentowała normy dotyczące liturgii mszalnej i brewiarzowej, a także specyficznych dla Zakonu form liturgicznych, jakimi był rytuał przyjęcia nowych członków oraz oficjum maryjne. Niemiecka badaczka podjęła też problem liturgii związanej z szafowaniem sakramentów: chrztu, namaszczenia, spowiedzi i eucharystii. Nie pominęła liturgicznych elementów w ramach posiedzeń kapitulnych, poświęcając także uwagę liturgicznej organizacji kultu relikwii oraz związanym z nim procesjom. Uwzględniła wreszcie liturgiczny wymiar memorii zmarłych członków zakonu. Większość prezentacji A. Löffler miała charakter poglądowego wykładu, który porządkował i systematyzował zagadnienia liturgiczne w kręgu zakonu niemieckiego. W mniejszym stopniu referat dotykał szczegółowych problemów. Do jednego z najważniejszych referentka nawiązała w końcowej części wystąpienia, 
w której wyraziła swoją akceptację dla poglądu Christofera Herrmanna negującego znaczenie liturgii i potrzeb liturgicznych jako decydującego determinanta kształtu architektonicznego domów/zamków konwentualnych Zakonu (wbrew starszym opiniom Mariana Arszyńskiego przychylającego się ku odwrotnej tezie). W interesującej dyskusji po referacie padły m.in. pytania dotyczące stopnia zróżnicowania zwyczajów liturgicznych w poszczególnych baliwatach zakonnych.

Drugim referatem dotyczącym strefy bałtyckiej było wystąpienie Sławomira Jóźwiaka (Toruń), który zaprezentował wyniki badań prowadzonych od kilku lat z Januszem Trupindą (Gdańsk) nad funkcjonowaniem domu głównego zakonu niemieckiego w Malborku w XIV i w pierwszej połowie XV w. (Organisation des Lebens in Marienburg nach schriftlichen Quellen) (niedawno opublikowane po polsku w obszernej monografii ${ }^{1}$ ). W pierwszej części wystąpienia toruński uczony przedstawił kwestie terminologiczne związane z zakresem znaczeniowym terminów stosowanych w średniowieczu do opisu układu przestrzennego w malborskim kompleksie zamkowym (m.in. „hus”, „stuba”, „gemach”, „sal”, „,orburg”). Podkreślił, że błędne w wielu przypadkach dotychczasowe rozumienie znaczenia owych określeń wynikało ze zbyt bezkrytycznego stosunku badaczy do dawnych tez niemieckich przedstawicieli kastellologii pruskiej - Bernharda Schmida, a zwłaszcza Conrada Steinbrechta. Jednym z głównych ustaleń obu polskich historyków było to dotyczące domniemanego kapitularza - ich zdaniem takie pomieszczenie nigdy na zamku konwentualnym nie funkcjonowało. W dalszej części referatu S. Jóźwiak podjął problematykę chronologii rozbudowy malborskiego kompleksu, w tym głównie obecnego tzw. Zamku Średniego, wskazując, że na podstawie źródeł pisanych początek prac budowalnych na tym obszarze można datować dopiero na przełom lat dwudziestych i trzydziestych XIV w. i kolejną dekadę. Związane to było z ukonstytuowaniem się przy konwencie malborskim siedziby wielkich mistrzów Zakonu. Jednocześnie toruński historyk wyraził opinię, że przybycie mistrza w 1309 r. akurat do Malborka miało charakter zupełnie przypadkowy, ponieważ żadnych prac budowalnych mających na celu ewentualne przygotowanie ówczesnego domu konwentualnego malborskiego na przyjęcie otoczenia głowy Zakonu przed tą datą nie podjęto. O ile chronologia prac budowlanych w zachodniej części tzw. pałacu wielkich mistrzów została przesunięta - w stosunku do dawniejszych opinii - na lata siedemdziesiąte XIV w., o tyle referent podkreślił zgodność starszych przypuszczeń z wynikami swoich badań dotyczących umiejscowienia pomieszczeń „prywatnych” wielkich mistrzów w północno-wschodniej części tzw. pałacu. Prezentując analizy dotyczące wybranych pomieszczeń lub większych części domu konwentualnego i zabudowań pierwszego przedzamcza (to jest obecnego tzw. Zamku Wysokiego i Średniego), S. Jóźwiak wyraził opinię, że w ciągu XIV stulecia malborski kompleks zamkowy mimo rozbudowy w coraz mniejszym stopniu był w stanie zaspokoić rosnące potrzeby lokalowe braci zakonnych i go-

${ }^{1}$ Sławomir Jóźwiak, Janusz TRUPINDA, Organizacja życia na zamku krzyżackim w Malborku w czasach wielkich mistrzów (1309-1457), Malbork 2007 (wyd. 2: Malbork 2011). 
ści. W referacie zostały także omówione zagadnienia funkcjonowania urzędów konwentualnych. Zwrócono również uwagę na kwestie dotyczące duchownych członków domu zakonnego. W tym kontekście S. Jóźwiak zdecydowanie wystąpił przeciwko tezom Rainera Zachariasa i Kazimierza Pospiesznego zakładającym pełnienie przez kościół w domu konwentualnym (tj. na obecnym tzw. Zamku Wysokim) funkcji miejsca pielgrzymkowego. Podczas ożywionej dyskusji wywołanej referatem toruńskiego uczonego Udo Arnold po raz kolejny przedstawił publicznie swoją opinię, zgodnie z którą osiedlenie się wielkiego mistrza Zakonu w Malborku w 1309 r. wynikało z konieczności, w jakiej ten znalazł się w wyniku splotu wielu niekorzystnych dla siebie i Zakonu okoliczności. Z tezą tą zgodził się Klaus Neitmann.

Trzecie wystąpienie przedobiednie dotyczyło badań archeologicznych przeprowadzonych w ostatnich latach w ramach pięciu ekspedycji wykopaliskowych na zamku zakonnym Montfort (Starkenberg, izr. Mivtzar haMonfor) w Palestynie (Das Leben im Montfort im Licht der Ausgrabungen). Tekst przygotowany przez kierownika tych badań Adriana Boasa (Haifa) pod jego nieobecność przeczytał Juhan Kreem. Warto zauważyć, że referat nawiązywał treścią do opublikowanej przez izraelskiego badacza w 2012 r. monografii archeologicznej poświęconej Montfortowi, a opartej na wstępnych opracowaniach przeprowadzonych na zamku badań ${ }^{2}$.

W ramach obrad popołudniowych zostały zaprezentowane trzy kolejne referaty. Wszystkie dotyczyły domów inflanckiej gałęzi Zakonu. W pierwszym z nich Ieva Ose (Ryga) podjęła problem struktury funkcjonalnej domów położonych na obszarze dzisiejszej Łotwy (Funktionen der Räume der Ordensburgen in Lettland (nach Bauresten und Schriftquellen)). W centrum uwagi referentki pozostawały głównie kaplice i refektarze konwentualne. Zaprezentowała ona kwestie związane z ich lokalizacją w obrębie obiektów w Rydze, Windawie (łot. Ventspils), Wenden (łot. Cēsis) i Segewoldzie (łot. Sigulda). Należy podkreślić, że wiele z założeń zamkowych na obszarze współczesnej Łotwy zostało poddanych w pierwszej dekadzie XXI w. badaniom archeologicznym, co nieco polepszyło stan wiedzy na temat ich kształtu architektonicznego. Na przykładzie zbudowanego w początkach XVI w. (kolejnego) zamku w Rydze łotewska badaczka pokazała problemy związane $\mathrm{z}$ interpretacją wczesnonowożytnych źródeł pisanych (w tym przypadku polskiej lustracji z 1590 r.) w kontekście określania funkcjonalności pomieszczeń zamkowych w okresie zakonnym - problem dobrze znany również badaczom zamków w Prusach.

W drugim referacie Villu Kadakas (Tallinn) przedstawił przebieg i wyniki badań archeologicznych przeprowadzonych w 1989 i 1999 r. w miejscu dawnego zamku Peude (est. Pöide) na Ozylii (est. Saarema) (Peude auf Ösel, eine typische

${ }^{2}$ Adrian J. BoAs, Montfort Castle, the Western Wing and the Great Hall. Preliminary report of excavations of the University of Haifa and the Society for the Study of the Crusades and the Latin East, August - September 2011, Haifa 2012. 
Ordensburg?). W tym przypadku badacze mają do czynienia z obiektem, którego funkcjonowanie skąpe źródła pisane poświadczają zaledwie dla pięćdziesięcioletniego okresu między 1290 a 1343 r., a masa architektoniczna na powierzchni ziemi zachowała się tylko dla jednego skrzydła (kościół). W referacie estoński archeolog omówił badania wykopaliskowe (nawiązując również do prac dziewiętnastowiecznych) i przedstawił hipotezy dotyczące faz budowlanych badanego obiektu (romański kościół (druga - trzecia ćwierć XIII w.) - zamek zakonu niemieckiego (koniec XIII w.) - rozbudowany, gotycki kościół tworzący jedno ze skrzydeł całego założenia obronnego (być może po 1343 r.)). Dyskusja, która wywiązała się po referacie, dotyczyła szczegółów interpretacyjnych niektórych odsłoniętych podczas badań elementów architektonicznych (m.in. przypuszczalnego przejścia z zamku do kościoła).

W ostatnim referacie pierwszego dnia zjazdu Arvi Haak (Tartu) zaprezentował rezultaty badań archeologicznych przeprowadzonych na zamku w Felinie (est. Viljandi) (Über den Lebenstil in der Ordensburg Fellin aufgrund archäologischer Quellen). Podobnie jak w przypadku zamku Peude, tak i tu badania archeologiczne wznowiono w pierwszej dekadzie obecnego wieku (po długiej przerwie od prac archeologicznych prowadzonych w czwartej ćwierci XIX w. i w końcu lat trzydziestych XX w.). Referent zaprezentował pozyskane $\mathrm{w}$ ich trakcie artefakty poświadczające różnorodne wymiary życia społeczności zamkowej (od elementów importowanej z Zachodu ceramiki, przez kości zwierzęce ukazujące mięsną konsumpcję mieszkańców, na wytworach rzemiosła rogowego i metalowego kończąc). Pokazał elementy architektoniczne świadczące o wzmocnieniu obronności założenia zamkowego w XV stuleciu (mur obwodowy i długi korytarz bramny zapewniający pogłębioną obronę wejścia na zamek).

Ogólnie można zauważyć, że - wyłączywszy problematykę liturgiczną - referenci zajmujący się zamkami zakonnymi prezentowali głównie materiał źródłowy poświadczający układ architektoniczny poszczególnych obiektów. Ukazywano zatem raczej fizyczne ramy życia na zamku aniżeli to, jak owo życie wyglądało $\mathrm{w}$ praktyce. Spostrzeżenie to ułatwia uzmysłowienie sobie faktu, $\mathrm{z}$ jak niewielkim zasobem źródeł, które mogłyby ukazać żywego mieszkańca zamku zakonu niemieckiego, mają do czynienia badacze tych obiektów w strefie bałtyckiej (ale i w Lewancie).

Spośród pięciu referatów wygłoszonych drugiego dnia konferencji tylko jeden dotyczył domów zakonnych położonych w strefie bałtyckiej. Aleksander Pluskowski (Reading) omówił poglądowo realizowany w ostatnich latach (2010-2014) projekt badawczy The Ecology of Crusading: The Environmental Impact of Conquest, Colonisation and Religious Conversion in the Medieval Baltic ${ }^{3}$. W wystąpieniu pt. Life in the Teutonic Order's castles in the eastern Baltic: an ecological perspective

\footnotetext{
${ }^{3}$ Por. stronę internetową projektu: http://www.ecologyofcrusading.com/methods.html (dostęp z 1 X 2014 r.), a także książkę A. Pluskowskiego: The archaeology of the Prussian Crusade. Holy war and colonisation, London-New York 2013.
} 
brytyjski uczony zaprezentował wybrane wyniki przeprowadzonych w Polsce, na Litwie, na Łowie i w Estonii badań archeologicznych ukazujących niektóre aspekty codziennego życia w domach Zakonu w Prusach i w Inflantach (m.in. Malbork, Elbląg, Radzyń, Nieszawa, Kłajpeda, Ryga, Rewel). Wśród wielu różnorodnych kwestii szczegółowych na uwagę zasługuje zwłaszcza ukazanie permanentnej obecności zwierząt domowych w obrębie założeń zamkowych (niewątpliwie głównie przedzamczy). Obok tego badania pokazują dużą różnorodność gatunkową zwierząt łownych w konsumpcji mieszkańców zamków zakonnych przy stosunkowo niewielkim ich udziale ilościowym w stosunku do zwierząt hodowlanych. Nawiązując do głównego kwestionariusza projektu - kwestii wpływu człowieka na środowisko w okresie krucjatowym w południowo-wschodniej strefie bałtyckiejreferent wskazał na XIV stulecie jako okres, w którym zmiany na zamkach i wokół nich następowały w stopniu największym i miały najintensywniejszy charakter. W tym miejscu można byłoby wyrazić jedynie życzenie, by te wielopłaszczyznowe badania były kontynuowane w następnych wydaniach projektu, dzięki czemu reprezentatywność pozyskanego materiału i tym samym jego poznawcza wartość mogłyby wzrosnąć.

Pozostałe referaty wygłoszone w drugim dniu obrad dotyczyły domów zakonnych położonych w krajach Rzeszy (Ursula Braasch-Schwersmann (Marburg): Alltag im Deutschordenshaus Marburg im 15. Jahrhundert; Hans Mol (Leiden): Alltag im Deutschordenskonvent zu Utrecht im 15. Jahrhundert; Michel van der Eycken (Bruksela) i Udo Arnold (Bonn): Das Leben im Konvent in Maastricht und in der Kommende Bekkevoort im 18. Jahrhundert) oraz na Sycylii (Kristjan Toomaspoeg (Lecce): Alltagsleben im Ordenshaus Palermo im Licht des Visitationsberichts von 1491). Większa różnorodność dostępnych źródeł, w tym zwłaszcza pisanych, niewątpliwie znalazła swój wyraz w tym, że zagadnienia podejmowane przez dopiero co wymienionych referentów w znacznie większym stopniu aniżeli w przypadku wystąpień „prusko-inflanckich” pokazywały „żywe barwy” poźnośredniowiecznej i wczesnonowożytnej codzienności domów zakonnych w Hesji, Utrechcie, Limburgii i na Sycylii.

Jako ostatni, niezaplanowany uprzednio referat wygłosił Bernhard Demel (OT), który po raz kolejny zaprezentował źródła archiwalne pozwalające na weryfikację daty nadania regaliów Rzeszy dla mistrza krajowego inflanckiego Woltera von Plettenberg (24 XII 1527 r., a nie jak dotychczas uważano 24 XII 1526 r.).

W podsumowaniu dwudniowych obrad Udo Arnold, wyrażając zadowolenie z intelektualnego plonu konferencji, podkreślił, że badania nad życiem codziennym w kręgu zakonu niemieckiego nadal znajdują się w fazie początkowej. Wezwał zarazem do pogłębionej współpracy między archeologami a historykami (w tym historykami sztuki).

Posiedzenie zakończyło się krótkim zwiedzaniem tallińskiej starówki oraz wspólną kolacją. 
Ostatniego dnia konferencji uczestnicy odbyli wycieczkę autokarową po zachodniej Wironii/Wirlandii (est. Virumaa) i po kraju Jerwen (est. Järva), zwiedzając zamki zakonne w Toolse (niem. Tolsburg) i w Rakvere (niem. Wesenberg) oraz wczesnogotyckie kościoły w Ambla (niem. Ampel) oraz w Järva-Madise (niem. St. Matthäi).

Należy też wspomnieć, że po zakończeniu obrad w pierwszym dniu zjazdu na walnym zgromadzeniu członków Międzynarodowej Komisji Historycznej podjęto decyzję o przyjęciu w jej szeregi kilku nowych członków. Przewodniczący Komisji przedłożył także uczestnikom zjazdu tekst Sprawozdania $z$ działalności za lata 2010-2012. Zatwierdzono również miejsce obrad i temat przyszłej konferencji, mającej się odbyć we wrześniu 2016 r. Uczestnicy kolejnego zjazdu obradować będą w Würzburgu nad zagadnieniami funkcjonowania zakonu niemieckiego w spektrum między wymiarem globalnym (Zakonu jako organizacji Kościoła rzymskiego) a regionalnym (Zakonu jako korporacji obejmującej poszczególne baliwaty i pojedyncze domy zakonne). Koncepcja ta pozwala żywić nadzieję na równie owocny jak w przypadku konferencji tallińskiej przebieg obrad za dwa lata.



